\title{
ANÁLISIS MICROBIOLÓGICO DE LECHE DE ORIGEN ORGÁNICO: ATRIBUTOS DESEABLES PARA SU TRANSFORMACIÓN
}

\author{
MICROBIOLOGICAL ANALYSIS OF ORGANIC MILK : DESIRABLE \\ ATTRIBUTES FOR ITS TRANSFORMATION
}

Gerardo Fuentes-Coto ${ }^{1}$, Rocío A. Ruiz-Romero ${ }^{2 *}$, José I. Sánchez-Gómez², Dolores N. Ávila-Ramírez², Jorge Escutia-Sánchez ${ }^{3}$

\begin{abstract}
${ }^{1}$ Facultad de Química (gefuco_jerry@hotmail.com) ${ }^{2}$ Facultad de Medicina Veterinaria y Zootecnia (rarr2212@unam.mx) (josei@unam.mx) (dnoemi1@yahoo.com.mx) 3Facultad de Ciencias. Universidad Nacional Autónoma de México, Ciudad Universitaria, Delegación Coyoacán. 04510. México, D.F. (jorge.escutia@gmail.com)
\end{abstract}

\section{RESUMEN}

El objetivo de este estudio fue analizar el proceso de producción de leche de vaca de un sistema familiar con manejo orgánico que sirve de materia prima para lácteos, con la finalidad de mejorar la eficiencia de su producción a través de un análisis de inocuidad y calidad con un estudio de trazabilidad microbiológico. Se evaluó la calidad e inocuidad de la leche cruda, pasteurizada y sus derivados, identificando los riesgos microbiológicos de la misma desde su obtención hasta su transformación, implementando un sistema de trazabilidad. La metodología consistió en recolectar muestras de leche de vacas Jersey (Bos taurus) en dos etapas: en la primera, en el máximo nivel de producción; en la segunda, los animales se encontraban próximos al secado. Se realizó un conteo de bacterias mesofílicas y coliformes en leche y lácteos, donde se obtuvieron cantidades por encima del límite permitido por la NOM-243-SSA1-2010. En el análisis bacteriológico general de leche se identificó a Staphylococcus aureus y Escherichia coli. Es necesario encaminar al personal que labora en unidad de lácteos en las buenas prácticas de higiene y de manufactura para disminuir las cargas microbiológicas, cumplir con las normas establecidas y asegurar la salud del consumidor.

Palabras clave: bacterias coliformes, bacterias mesofílicas, leche de vaca, producción orgánica.

\section{INTRODUCCIÓN}

L a leche ha sido recomendada por la Organización de las Naciones Unidas para las Agricultura y por la Organización de las Naciones Unidas para la Educación (FAO y UNESCO,

* Autor responsable * Author for correspondence. Recibido: agosto, 2013. Aprobado: octubre, 2013. Publicado como ARTÍCULO en ASyD 10: 419-432. 2013.

\section{Abstract}

The objective of this study was to analyze the production process of cow milk in a family system with organic management, which serves as raw material for dairy products, with the aim of improving the efficiency of their production through an analysis of innocuousness and quality with a study of microbiological traceability. The quality and innocuousness of the raw, pasteurized milk and its dairy products was evaluated, identifying the microbiological risks from its extraction to its transformation, by implementing a traceability system. The methodology consisted of collecting samples from Jersey dairy cows (Bos Taurus) in two stages: first, at the maximum level of production; second, when animals were close to drying up. A count of mesophile and coliform bacteria was performed in milk and dairy products, where amounts above the limit allowed by the NOM-243SSA1-2010 were obtained. In the general bacteriologic analysis of the milk, Staphylococcus aureus and Escherichia coli were identified. It is necessary to direct the personnel who work at the dairy unit towards good hygiene and manufacture practices to decrease the microbiologic charges and fulfill the regulations established, as well as guarantee the health of the consumer.

Key words: coliform bacteria, mesophile bacteria, cow milk, organic production.

\section{INTRODUCTION}

$\mathrm{M}$ ilk has been recommended by the Food and Agriculture Organization for the United Nations and by the United Nations Educational, Scientific and Cultural Organization (FAO and UNESCO) as an essential food in the human diet, primarily for children, which is why its 
respectivamente) como un alimento indispensable en la alimentación humana, principalmente para niños, por lo que su producción y abasto es parte de las estrategias de seguridad alimentaria en muchos países, de acuerdo con los Fideicomisos Instituidos en Relación con la Agricultura (FIRA) en 2001.

En México, los sistemas campesinos aportan alrededor de $30 \%$ de la producción de leche. El número aproximado de vacas en este sistema es de 1470 000, distribuidas en más de 100 mil unidades productivas, de acuerdo con estudios realizados por Castro et al. (2001). Uno de los desafíos que éstas enfrentan se relacionan con el cumplimiento de estándares de calidad que establece la Norma Mexicana para leche cruda PROYNMX-F-700- COFOCALEC-2012, y la competencia con la leche y productos lácteos de otras empresas, como consecuencia de la apertura comercial dentro del marco del Tratado de Libre Comercio de América del Norte, ya sea por el precio o por la calidad.

Los sistemas campesinos de producción de leche en el centro de México se definen como unidades de producción con pequeñas superficies de tierra, aunque pueden no tener tierra de cultivo. Cuentan con un máximo de 20 de vacas y un mínimo de tres; este ganado es producto de cruzas de Suizo, criollo y predominantemente Holstein de acuerdo con informes realizados por Castelán et al. (1997). La producción de leche se vende a agroindustrias locales procesadoras de lácteos, queserías artesanales y empresas transnacionales, o se comercializan mediante intermediarios, quienes la recolectan directamente de la unidad de producción y luego la llevan a las ciudades donde se vende de manera directa al público, sin ningún tratamiento previo de enfriamiento o pasteurización (Lampkin, 1990). En la Ciudad de México, Espinoza-Ortega et al. (2005) reportan que la calidad no es un elemento importante para determinar el precio que se paga a los productores campesinos por la leche, aun si se considera que para los intermediarios es más importante el volumen líquido que la producción de sólidos de leche o la calidad bacteriológica.

Desafortunadamente existe poca información sobre la calidad de la leche que se produce en sistemas campesinos, debido a que a los productores nunca se les ha exigido un nivel mínimo de calidad, a pesar de que la legislación mexicana lo establece. Lampkin (1990) define a los sistemas de producción orgánica de leche como un complejo ganadero que aspira a producir leche de alta calidad nutritiva, practicando production and supply are part of the strategies for food security in many countries, according to the Trusts Fund for Rural Development (Fideicomisos Instituidos en Relación con la Agricultura, FIRA) in 2001.

In México, peasant systems contribute around $30 \%$ of milk production. The approximate number of cows in this system is 1470000 , distributed in more than 100 thousand productive units, according to studies performed by Castro et al. (2001). One of the challenges that these face is related with the fulfillment of standards of quality that the Mexican Norm for raw milk, PROY-NMX-F-700COFOCALEC-2012, establishes, as well as the competition with milk and dairy products from other companies, as consequence of the commercial openness within the framework of the North America Free Trade Agreement, whether over price or over quality.

Peasant milk production systems in the center of México are defined as production units with small land surfaces, although they may not have cultivation lands. They have a maximum of 20 cows and a minimum of three; these cattle are the product of crosses between Swiss, Creole and predominantly Holstein, according to reports carried out by Castelán et al. (1997). Milk production is sold to local dairy processing agro-industries, artisanal cheese producers and transnational companies, or it is marketed through intermediaries, who collect it directly from the production unit and then take it to the cities where it is sold directly to the public, without any prior treatment for cooling or pasteurization (Lampkin, 1990). In Mexico City, Espinoza-Ortega et al. (2005) report that the quality is not an important element to determine the price that is paid to the peasant producers for the milk, even if taking into account that the liquid volume is more important for the intermediaries than the production of milk solids or the bacteriologic quality.

Unfortunately, there is little information about the quality of the milk that is produced in peasant systems, because a minimum level of quality has never been demanded from the producers, even when the Mexican legislation establishes it. Lampkin (1990) defines the organic milk production systems as a livestock production complex that aspires to produce milk of high nutritious quality, practicing production methods that reject the use 
métodos de producción que rechazan el empleo de productos agroquímicos manufacturados (fertilizantes, pesticidas, reguladores de crecimiento y aditivos a los alimentos), que puede funcionar en forma de ciclo cerrado y recicla residuos orgánicos, protegiendo el medio y la vida natural. Las empresas artesanales requieren la incorporación de análisis microbiológicos con la intención de garantizar la inocuidad y la calidad de los productos, por lo que demandan la participación de los profesionistas y técnicos capacitados para resolver necesidades científico-tecnológicas que contribuyan a mejorar la eficiencia de sus procesos productivos y/o estandarizar los procesos industriales, como lo menciona Muchnik (2006).

La producción de leche en la unidad de estudio presenta un manejo orgánico en cuanto a su alimentación, con la intención de identificar en qué etapa del proceso se encontraron riesgos microbiológicos. Se diseñó una estrategia de trazabilidad de las muestras de leche durante el pico de lactación de las vacas y en la etapa próxima al secado, por lo que el objetivo de este estudio fue analizar el proceso de producción de leche de vaca de un sistema familiar con manejo orgánico que sirve de materia prima para lácteos y para mejorar la eficiencia de su producción a través de un análisis de inocuidad y calidad con un estudio de trazabilidad microbiológico.

\section{Metodología}

\section{Origen de la muestra}

Se trabajó con leche de vacas Jersey de tres años de edad en promedio, con desde uno hasta dos partos, clínicamente sanas, criadas bajo un sistema de producción con manejo orgánico en una empresa familiar ubicada en la Delegación Magdalena Contreras, Distrito Federal, México. La empresa posee la certificación orgánica en los productos agrícolas que produce, como fresa (Fragaria vesca), jitomate (Lycopersicum esculentum) y tomate (Physalis ixocarpa), por lo que este estudio contribuye a la búsqueda de la certificación orgánica de lácteos. La empresa cuenta con siete vacas Jersey (Bos taurus); la dieta del ganado bovino consta de ensilado de maíz (Zea mays), rastrojo de maíz, heno de ebo (Vicia sativa), zacate de maíz fresco y salvado de trigo (Triticum aestivum). También se les proporciona un concentrado comercial de acuerdo con la edad del animal y, finalmente, se les of agrichemical manufactured products (fertilizers, pesticides, growth regulators and food additives), which can function in the form of a closed cycle and recycle organic residues, protecting the environment and natural life. The artisanal enterprises require the incorporation of microbiological analyses with the intention of guaranteeing the innocuousness and quality of the products, which is why they demand the participation of professionals and technicians trained to solve the scientific-technological needs that contribute to improve the efficiency of their productive processes and/or standardize industrial processes, as is mentioned by Muchnik (2006).

Milk production in the study unit presents an organic management in terms of the diet. With the intention of identifying in what stage of the process microbiological risks were found, a strategy for traceability of the milk samples was designed during the peak of the cows' lactation and during the stage near the dry-up. Therefore, the objective of this study was to analyze the cow milk production process of a family system with organic management that serves as raw material for dairy products, and to improve the efficiency of its production through an analysis of innocuousness and quality with a study of microbiologic traceability.

\section{Methodology}

\section{Origin of the sample}

The study was done with Jersey cows of three years of age in average, with one to two births, clinically healthy, bred under a production system with organic management in a family enterprise located in the Delegación Magdalena Contreras, Distrito Federal, México. The company has organic certification for the agricultural products it produces, such as strawberry (Fragaria vesca), tomato (Lycopersicum esculentum) and green tomato (Physalis ixocarpa), so this study contributes to the quest for the organic certification for dairy products. The enterprise has seven Jersey cows (Bos Taurus); the cattle diet is maize ensilage (Zea mays), maize stubble, vetch hay (Vicia sativa), fresh maize fodder and wheat bran (Triticum aestivum). They are also given a commercial concentrate according to the animal's age and, finally, two dietary supplements. Milking is 
brindan dos suplementos alimenticios. La ordeña es de tipo mecánica y se realiza dos veces al día; la mayor parte de la producción es para la elaboración artesanal de lácteos. La leche recién obtenida es llevada al taller de lácteos para su refrigeración y se somete a pasteurización lenta, que corresponde a una temperatura de $63^{\circ} \mathrm{C}$ durante 30 minutos.

\section{Características del muestreo}

La toma de muestras se llevó a cabo en dos etapas.

\section{Primera etapa de muestreo "Maxima producción"}

Primera etapa. El muestreo se realizó cuando la cantidad de leche se encontraba en su máxima producción. Para lograr que los animales alcanzaran al mismo tiempo el pico máximo de producción de leche, se sincronizó el ciclo estral de las vacas para inseminarlas artificialmente, de modo que la fecha de parto fuera similar y el ciclo de producción de leche fuera homogéneo. Los muestreos consistieron en la desinfección de los pezones con torunda y alcohol a $70 \%$, y la extracción manual y el desecho de los tres primeros chorros de leche de cada una de las glándulas; posteriormente, se obtuvieron $20 \mathrm{ml}$ de leche de las cuatro glándulas en frascos nuevos, estériles y herméticos. En el taller de lácteos se tomaron $20 \mathrm{ml}$ de leche cruda del tanque de almacenamiento, leche sometida a pasteurización lenta $\left(63{ }^{\circ} \mathrm{C} / 30 \mathrm{~min}\right)$, y se tomaron muestras de queso tipo Oaxaca, panela y yogurt natural; por último, se tomaron muestras de las palmas de las manos y garganta al personal que labora en el taller de lácteos, utilizando hisopos estériles que fueron colocados en medio de transporte de Stuart. Todas las muestras se conservaron en refrigeración hasta que fueron remitidas al Laboratorio de Microbiología del Departamento de Medicina y Zootecnia de Rumiantes de la Facultad de Medicina Veterinaria y Zootecnia de la Universidad Nacional Autónoma de México (FMVZ-UNAM) para su análisis microbiológico.

Determinación de bacterias mesofílicas. Cada una de las muestras de leche fueron homogenizadas durante 30 segundos, utilizando un agitador automático. Se tomaron $10 \mathrm{ml}$ de leche y $10 \mathrm{~g}$ en el caso de los quesos, y cada una de las muestras se mezcló con $90 \mathrm{ml}$ de agua peptonada estéril; ésta constituyó la primera mechanical and it is carried out twice a day; most of the production is for the artisanal elaboration of dairy products. The recently obtained milk is taken to the dairy workshop for its refrigeration and it is subjected to slow pasteurization, which corresponds to a temperature of $63{ }^{\circ} \mathrm{C}$ for 30 minutes.

\section{Characteristics of the sampling}

The samples were taken in two stages.

\section{First stage of the sampling: "maximum production"}

First stage. The sampling was carried out when the amount of milk was at its maximum production. To manage for animals to reach the maximum peak of milk production at the same time, the estrus cycle of the cows was synchronized to inseminate them artificially, so that the birth date was similar and the milk production cycle homogeneous. The samples consisted in disinfecting the nipples with a swab and alcohol at $70 \%$, manual extraction, and discarding the first three streams of milk from each of the glands; later, $20 \mathrm{ml}$ of milk were obtained from the four glands in new, sterile and hermetic jars. In the dairy workshop, $20 \mathrm{ml}$ of raw milk from the storage tank, milk subjected to slow pasteurization $\left(63{ }^{\circ} \mathrm{C} / 30 \mathrm{~min}\right.$ ), and samples from the Oaxaca style cheese, panela cheese and natural yoghurt were taken; lastly, samples from the palms of the hands and throats of the staff who works in the dairy workshop were taken, using sterile swabs that were placed in a Stuart transportation medium. All the samples were kept under refrigeration until they were sent to the Microbiology Laboratory of the Ruminant Medicine and Zoo Technology Department in the Veterinary Medicine and Zoo Technology School of the Universidad Nacional Autónoma de México (FMVZ-UNAM) for their microbiological analysis.

Determination of mesophile bacteria. Each one of the milk samples were homogenized during 30 seconds, using an automatic agitator. Then, $10 \mathrm{ml}$ of milk and $10 \mathrm{~g}$ in the case of the cheeses were taken, and each one of the samples was mixed with $90 \mathrm{ml}$ of sterile peptonated water; this constituted the first dilution of the sample $\left(10^{-1}\right)$. Later, serial decuple dilutions were performed, transferring $1 \mathrm{ml}$ of the initial dilution into $9 \mathrm{ml}$ of sterile 
dilución de la muestra $\left(10^{-1}\right)$. Posteriormente se realizaron diluciones decuples seriadas, transfiriendo $1 \mathrm{ml}$ de la dilución inicial a $9 \mathrm{ml}$ de agua peptonada estéril hasta la dilución $10^{-8}$. Una vez terminadas las diluciones, se utilizó la técnica descrita por Miles y Misra, modificada por Slack y Wheldon (1978), en la cual se depositaron $20 \mu \mathrm{l}$ de cada dilución en la superficie de una placa de agar para cuenta en placa, realizando el goteo desde una altura de $2.5 \mathrm{~cm}$ y depositando tres gotas por cada dilución; una vez que se secaron las gotas, se incubaron durante 24 horas a $30^{\circ} \mathrm{C}$. Transcurrido este tiempo se revisó el crecimiento de colonias bacterianas en cada una de las diluciones, descartando aquellas colonias que se encontraban fuera del área de inoculación. Se seleccionaron aquellas diluciones en las que se observó la presencia de colonias lo suficientemente separadas (no confluentes) para realizar el conteo en las tres gotas inoculadas, se obtuvo un promedio de las colonias, y se realizó el cálculo para obtener el número de colonias bacterianas presentes por $\mathrm{ml} \mathrm{de} \mathrm{muestra,} \mathrm{ajustando} \mathrm{el}$ resultado de acuerdo con la dilución en la que se realizó el conteo.

Determinación de bacterias coliformes. Para determinar la presencia de bacterias coliformes se utilizó la técnica del Número Más Probable (NMP), que consistió en realizar diluciones decuples seriadas, como se mencionó anteriormente, llegando hasta la dilución $10^{-8}$. Se depositó $1 \mathrm{ml}$ de cada dilución a cada uno de los tres tubos, conteniendo $10 \mathrm{ml}$ de caldo lactosado simple con tubo de Durham invertido para determinar la presencia de gas. Los tubos se incubaron durante 24 horas a $37^{\circ} \mathrm{C}$ y, transcurrido este tiempo, se revisaron los tubos que presentaron formación de gas, es decir, en los que se observó la presencia de burbujas en los tubos de Durham $\mathrm{y}$ aquellos que fueron negativos a la presencia de gas, se incubaron 24 horas más. Transcurrido este tiempo, se procedió a la lectura de los resultados, se seleccionó la dilución más alta en la que se observó la presencia de gas en los tres tubos con caldo lactosado simple, y se tomó una asada de los tubos con gas para sembrar en una placa de agar MacConkey, para determinar si el gas se debió a la presencia de bacterias coliformes fecales. Esta placa se incubó 24 horas a $37{ }^{\circ} \mathrm{C}$ y se determinó la presencia de colonias de bacterias coliformes fecales, las cuales se caracterizan por presentar un color rosa. peptonated water until a dilution of $10^{-8}$. Once the dilutions were finished, the technique described by Miles and Misra, modified by Slack and Wheldon (1978), was used, where $20 \mu \mathrm{l}$ of each dilution was placed on the surface of an agar plate for counting on the plate, performing dripping from a height of $2.5 \mathrm{~cm}$ and depositing three drops for each dilution; once the drops dried, they were incubated for 24 hours at $30^{\circ} \mathrm{C}$. After this time passed, the growth of bacteria colonies in each one of the dilutions was examined, discarding the colonies that were outside the area of inoculation. The dilutions where the presence of colonies that were sufficiently apart (non-confluent) was observed, were selected, to carry out the count on the three inoculated drops; an average of the colonies was obtained, and the calculation was done to obtain the number of bacteria colonies present per $\mathrm{ml}$ of sample, adjusting the result according to the dilution at which the counting was performed.

Determination of coliform bacteria. To determine the presence of coliform bacteria, the technique of the Most Probable Number (MPN) was used, which consisted in performing serial decuple dilutions, as was mentioned before, until reaching dilution $10^{-8}$. The amount of $1 \mathrm{ml}$ from each dilution was deposited in each one of the three tubes, containing $10 \mathrm{ml}$ of simple lactoserum with an inverted Durham tube, to determine the presence of gas. The tubes were incubated for 24 hours at $37{ }^{\circ} \mathrm{C}$ and, after this time, the tubes were that presented gas formation were examined; that is, the tubes where the presence of bubbles in the Durham tubes was observed, and those that were negative to the presence of gas were incubated for 24 more hours. After this time, the next step was to read the results, then the highest dilution at which the presence of gas was observed in the three tubes with simple lactoserum was selected, and a sample was taken from the tubes with gas to inoculate a MacConkey agar plate, to determine if the gas was due to the presence of fecal coliform bacteria. This plate was incubated for 24 hours at $37^{\circ} \mathrm{C}$ and the presence of fecal coliform bacteria was determined, which are characterized by having a pink color.

Isolation and identification of bacteria. To identify the facultative bacteria in the milk and 
Aislamiento e identificación bacteriana. Para identificar bacterias facultativas en la leche y en las muestras de hisopos, se colocaron $30 \mu \mathrm{L}$ de la leche y una muestra de los hisopos, respectivamente, en una placa de agar sangre y agar McConkey en la primera estría para realizar el primocultivo. Ambas placas se incubaron a $37^{\circ} \mathrm{C}$ durante 24 horas en condiciones de aerobiosis; en caso de observar crecimiento, se incubaron durante $48 \mathrm{~h}$ más hasta descartar crecimiento bacteriano. Los cultivos fueron examinados para identificar la morfología macroscópica de las colonias desarrolladas y estimar su número relativo, de acuerdo con el número de cuadrantes del agar donde se observó crecimiento bacteriano. A partir de las colonias representativas se realizó un frotis fijo teñido con Gram para guiar la identificación bioquímica recomendada por Carter (1984).

\section{Segunda etapa de muestreo "declive de la lactación"}

Estrategia de muestreo. Este muestreo corresponde al periodo donde la producción de leche se encontraba en declive. Se recolectaron $20 \mathrm{ml}$ de leche de las últimas vacas en producción y leche del tanque de almacenamiento $y$, posteriormente, las muestras fueron transportadas de la misma manera descrita anteriormente. Se realizó un segundo hisopado de manos y garganta al personal del taller de lácteos, así como en la máquina ordeñadora, el tanque de almacenamiento y la mesa de trabajo; los hisopos fueron transportados en medio de Stuart a temperatura de refrigeración al Laboratorio de Microbiología del Departamento de Medicina y Zootecnia de Rumiantes de la FMVZ-UNAM para su análisis microbiológico, realizando el mismo método para determinar bacterias mesofilicas, coliformes y análisis bacteriológico, como se describió anteriormente.

Evaluación de los atributos de calidad para la transformación de la leche. La evaluación de calidad de la leche como materia prima se realizó mediante implementación de pruebas rápidas de campo en el área de ordeńa y de andén en el taller de lácteos.

Prueba de California. Esta prueba se utilizó para diagnosticar mastitis subclínica, siguiendo la metodología descrita por Blowey y Edmondson (1995); consistió en recolectar aproximadamente $3 \mathrm{ml}$ de leche de cada glándula y colocarlos en cada una de the swab samples, $30 \mu \mathrm{L}$ of milk and a sample of the swab were placed in a blood agar plate and on McConkey agar on the first groove to carry out the primeculture. Both plates were incubated at $37^{\circ} \mathrm{C}$ for 24 hours under aerobiosis conditions; in the case of observing the growth, they were incubated for 48 more hours until bacterial growth could be ruled out. The cultures were examined to identify the macroscopic morphology of the colonies developed and to estimate their relative number, according to the number of quadrants in the agar where bacterial growth was observed. From the representative colonies, a fixed smear dyed with Gram was performed, to guide the biochemical identification recommended by Carter (1984).

\section{Second stage of sampling: "decline of lactation"}

Sampling strategy. This sampling corresponds to the period when milk production is in decline. From the last cows in production, $20 \mathrm{ml}$ of milk were collected, and milk from the storage tank; later, the samples were transported in the same manner as described previously. A second swab of hands and throat of the dairy workshop staff was performed, as well as of the milking machine, the storage tank and the work table; the swabs were transported in Stuart medium at refrigeration temperature to the Microbiology Laboratory of the Ruminant Medicine and Zoo Technology of the FMVZ-UNAM for their microbiological analysis, and the same method was performed to determine mesophile and coliform bacteria, and the bacteriologic analysis, as described previously.

Evaluation of the quality attributes for milk transformation. The evaluation of milk quality as raw material was done through the implementation of fast field tests in the milking and platform area of the dairy workshop.

California test. This test was used to diagnose subclinical mastitis, following the methodology described by Blowey and Edmondson (1995); it consisted of collecting approximately $3 \mathrm{ml}$ of milk from each gland and placing it in each one of the plates of the palette used in this test, to which the same volume of the California reactive is added, 
las placas de la paleta utilizada en esta prueba, a la cual se le adiciona igual volumen del reactivo de California compuesto por un detergente aniónico (alquil-aril-sulfonato de sodio), que provoca la liberación de ADN de las células somáticas (células inflamatorias y epiteliales) presentes en la glándula mamaria y púrpura de bromocresol como indicador de $\mathrm{pH}$. Con esta prueba se diagnosticó a las vacas que presentaban procesos inflamatorios en una o varias glándulas mamarias.

Pruebas rápidas de andén en leche. En lo que refiere al análisis de la calidad de la leche para la transformación de lácteos, se realizaron pruebas sensoriales como olor, color, sabor y textura y pruebas fisicoquímicas, como medición de temperatura, $\mathrm{pH}$, densidad y termoestabilidad (prueba de alcohol).

Análisis sensorial. Se tomaron de 5 a $10 \mathrm{ml}$ de la muestra, colocándola en un vaso de plástico transparente, de preferencia con un fondo, y se evaluó olor, color, sabor y textura.

Determinación de temperatura. Se tomaron $30 \mathrm{ml}$ de muestra de leche de vaca, previamente homogeneizada, y la temperatura se registró con un termómetro digital calibrado.

Determinación de $\mathbf{p H}$. Se colocaron $30 \mathrm{ml}$ de la muestra en un vaso de precipitado, se encendió el potenciómetro y se introdujo en la muestra analizada para registrar la lectura obtenida.

Prueba de acidez. Se tomaron $9 \mathrm{ml}$ de leche cruda o pasteurizada, colocándola en un matraz Erlenmeyer de $50 \mathrm{ml}$, titulando con hidróxido de sodio al $0.1 \mathrm{~N}$, hasta observar un viraje a color rosa.

Prueba de densidad. La muestra se homogenizó totalmente y se vertió en una probeta de $250 \mathrm{ml}$ hasta el aforo, evitando hacer espuma. Se introdujo el lactodensímetro, dejándolo flotar libremente hasta un nivel constante; se realizó la lectura en la parte superior del menisco y se registró la temperatura del termómetro interno del lactodensímetro.

Alcohol y neutralizantes. Se tomaron $5 \mathrm{ml}$ en un tubo de ensaye, se agregaron $5 \mathrm{ml}$ de alcohol, deslizándolo por las paredes, y se mezcló por inversión, sin agitar; se observó la existencia de coagulación a contra luz. made up of an anionic detergent (sodium alkyl-arilsulfonate), which provokes the release of DNA from the somatic cells (inflammatory and epithelial cells) present in the mammary gland, and bromocresol purple as indicator of $\mathrm{pH}$. With this test, the cows that presented inflammatory processes in one or several mammary glands were diagnosed.

Fast tests on the milk platform. With regards to the quality analysis of milk for its transformation into dairy products, sensory tests for odor, color, taste and texture were performed, as well as physicochemical tests, such as measuring temperature, $\mathrm{pH}$, density and thermostability (alcohol test).

Sensory analysis. From the sample, 5 to $10 \mathrm{ml}$ were taken, placed in a transparent plastic cup, preferably with a bottom, and odor, color, taste and texture were evaluated.

Determination of temperature. From the cow milk sample, $30 \mathrm{ml}$ were taken, which had been previously homogenized, and the temperature was measured with a calibrated digital thermometer.

Determination of the $\mathbf{p H}$. From the sample, $30 \mathrm{ml}$ were placed in a precipitate cup, the potenciometer was turned on, and the sample analyzed was introduced to record the reading obtained.

Acidity test. From raw or pasteurized milk, $9 \mathrm{ml}$ were taken and placed in a $50 \mathrm{ml}$ Erlenmeyer flask, titrating with sodium hydroxide at $0.1 \mathrm{~N}$, until a change to pink color was observed.

Density test. The sample was homogenized completely and poured into a $250 \mathrm{ml}$ test tube up to capacity, avoiding making foam. The lactodensimeter was introduced, letting it float freely until a constant level; a reading was carried out on the upper part of the meniscus and the temperature from the inner thermometer of the lactodensimeter was recorded.

Alcohol and neutralizers. In a test tube, $5 \mathrm{ml}$ were placed and $5 \mathrm{ml}$ of alcohol were added, sliding it down the walls; it was mixed by inversion, without shaking; the existence of coagulation was observed against a backlight. 


\section{Resultados y Discusión}

\section{Primera etapa de muestreo}

Determinación de bacterias mesofílicas. Para la leche del tanque de almacenamiento para leche bronca 1 se obtuvo un total de $135 \times 10^{6} \mathrm{UFC} / \mathrm{ml}$, para la del tanque 2 se registraron $32 \times 10^{2} \mathrm{UFC} / \mathrm{ml}$, y para la sometida a pasteurización lenta se obtuvieron $92 \times 10^{1} \mathrm{UFC} / \mathrm{ml}$.

Determinación de bacterias coliformes. Todas las muestras de leche presentaron menos de $3 \mathrm{NMP} / \mathrm{ml}$ de leche, excepto en el caso da una muestra de leche cruda donde se obtuvieron $23 \mathrm{NMP} / \mathrm{ml}$ de muestra y la leche del tanque de almacenamiento donde se obtuvieron $15 \times 10^{7} \mathrm{NMP} / \mathrm{ml}$ de muestra.

Aislamiento e identificación bacteriana. Se aislaron e identificaron dos agentes microbianos específicos: Escherichia coli, en todas la muestras, incluyendo la leche de tanque y leche pasteurizada, y Staphylococcus aureus, que se aisló únicamente en la muestra de leche bronca. (Cuadro 1).

\section{Evaluaciones microbiológicas en lácteos}

Determinación de bacterias mesofílicas. En el caso del queso panela se obtuvieron $105 \times 10^{6} \mathrm{UFC} / \mathrm{g}$ y en el tipo Oaxaca, $11 \times 10^{7} \mathrm{UFC} / \mathrm{g}$.

\section{Results AND Discussion}

\section{First stage of the sampling}

Determination of mesophile bacteria. For the milk from the storage tank for raw milk 1 , a total of $135 \times 10^{6} \mathrm{UFC} / \mathrm{ml}$ was obtained; for the milk from tank 2, $32 \times 10^{2} \mathrm{UFC} / \mathrm{ml}$ were recorded; and for the milk subjected to slow pasteurization, $92 \times 10^{1} \mathrm{UFC} /$ $\mathrm{ml}$ was obtained.

Determination of coliform bacteria. All the milk samples presented less than $3 \mathrm{MPN} / \mathrm{ml}$ of milk, except in the case of a raw milk sample where 23 $\mathrm{MPN} / \mathrm{ml}$ of the sample were obtained, and the milk from the storage tank where $15 \times 10^{7} \mathrm{MPN} / \mathrm{ml}$ of the sample were obtained.

Bacterial isolation and identification. Two specific microbial agents were isolated and identified: Escherichia coli, in every sample, including milk from the tank and pasteurized milk, and Staphylococcus aureus, which was isolated only from the raw milk sample (Table 1).

\section{Microbiological evaluations in dairy products}

Determination of mesophile bacteria. In the case of panela cheese, $105 \times 10^{6} \mathrm{UFC/g}$ were obtained, and in the Oaxaca type, $11 \times 10^{7} \mathrm{UFC} / \mathrm{g}$.

Cuadro 1. Determinación de microorganismos mesofílicos y coliformes en leche de la Unidad de Lácteos Xochimancas. Table 1. Determination of mesophile and coliform microorganisms in milk from the Xochimancas Dairy Unit.

\begin{tabular}{|c|c|c|c|c|}
\hline Etapa del proceso & Unidad de muestreo & $\begin{array}{l}\text { Número de mesofílicos } \\
(\mathrm{UFC} / \mathrm{ml})\end{array}$ & $\begin{array}{l}\text { Número de coliformes } \\
\qquad(\mathrm{NMP} / \mathrm{ml})\end{array}$ & $\begin{array}{c}\text { Especies } \\
\text { bacterianas } \\
\text { identificadas }\end{array}$ \\
\hline \multirow[t]{5}{*}{ Ordeña } & Vaca 1799 & 460 & $\leq 3$ & E. coli \\
\hline & Vaca 9081 & 60 & $\leq 3$ & E. coli \\
\hline & Vaca 1764 & 260 & 23 & E. coli \\
\hline & Holstein & 200 & $\leq 3$ & E. coli \\
\hline & 764 & 120 & $\leq 3$ & S. aureus \\
\hline \multirow[t]{2}{*}{ Almacenamiento } & Tanque de leche bronca1 & $* 135 \times 106$ & $* 150 \times 106$ & E. coli \\
\hline & Tanque de leche bronca2 & 3200 & $\leq 3$ & E. coli \\
\hline Pasteurización & Tanque leche pasteurizada & 920 & $\leq 3$ & E. coli \\
\hline
\end{tabular}

*Por encima del límite máximo permitido por la NOM-243-SSA1-2010. • Above the maximum limit allowed by the NOM-243SSA1-2010. 
Determinación de bacterias coliformes. Para el queso Oaxaca se obtuvieron $7 \times 10^{4} \mathrm{NMP} / \mathrm{g}$ y en el panela, $9 \times 10^{7} \mathrm{NMP} / \mathrm{g}$.

Evaluaciones microbiológicas en el personal y los implementos. En el análisis bacteriológico general realizado en el personal que labora en el taller de lácteos, sólo se identificó a Streptococcus spp en la mano derecha de un operador, los hisopos restantes de manos y gargantes fueron negativos a crecimiento bacteriano. (Cuadro 2).

\section{Segunda etapa de muestreo}

Determinación de bacterias mesofílicas. En uno de los animales se obtuvieron $5 \times 10^{4} \mathrm{UFC} / \mathrm{ml}$ de leche bronca; para la muestra de leche cruda de tanque de almacenamiento se contabilizaron $15 \times 10^{6} \mathrm{UFC} / \mathrm{ml}$.

Determinación de bacterias coliformes. Para la muestra de leche cruda del tanque de almacenamiento se obtuvieron $150 \times 10^{3} \mathrm{NMP} / \mathrm{ml}$. (Cuadro 3).

Evaluaciones microbiológicas en el personal y los implementos. De todo el personal que labora en el taller de lácteos, se logró aislar a Streptococcus spp de la garganta; en las pezoneras de la máquina ordeñadora se detectó la presencia de E. coli.

\section{Pruebas rápidas de andén e implicaciones en la calidad de la leche como materia prima}

Evaluación sensorial. Los resultados de estas pruebas se presentan en el Cuadro 4.

Cuadro 2. Registro de resultados para microorganismos mesofílicos y coliformes en lácteos producidos en Unidad de Lácteos Xochimancas.

Table 2. Registry of results for mesophile and coliform microorganisms in dairy produced at the Xochimancas Dairy Unit.

\begin{tabular}{lccc}
\hline $\begin{array}{c}\text { Producto } \\
\text { lácteo }\end{array}$ & $\begin{array}{c}\text { Número de } \\
\text { mesofílicos } \\
(\mathrm{UFC} / \mathrm{ml})\end{array}$ & $\begin{array}{c}\text { Número de } \\
\text { coliformes } \\
(\mathrm{NMP} / \mathrm{g})\end{array}$ & $\begin{array}{c}\text { Especies } \\
\text { bacterianas } \\
\text { identificadas }\end{array}$ \\
\hline Queso panela & ${ }^{*} 105 \times 106$ & ${ }^{*} 9 \times 106$ & $\mathrm{NA}$ \\
Queso Oaxaca & ${ }^{*} 11 \times 107$ & ${ }^{*} 7 \mathrm{X} 104$ & $\mathrm{NA}$ \\
Yogurt & $5 \times 103$ & $\leq 3$ & $\mathrm{NA}$ \\
\hline
\end{tabular}

*Por encima del límite máximo permitido por la NOM-121SSA-1994. Above the maximum limit allowed by the NOM121- SSA-1994.
Determination of coliform bacteria. For Oaxaca cheese, $7 \times 10^{4} \mathrm{MPN} / \mathrm{g}$ were obtained and in panela, $9 \times 10^{7} \mathrm{MPN} / \mathrm{g}$.

Microbiological evaluations on the personnel and implements. In the general bacteriological analysis carried out with the staff that works in the dairy workshop, only Streptococcus spp. was identified, on the right hand of an operator; the remaining swabs from hands and throats were negative to bacterial growth (Table 2).

\section{Second stage of the sampling}

Determination of mesophile bacteria. In one of the animals, $5 \times 10^{4} \mathrm{UFC} / \mathrm{ml}$ were obtained from the raw milk; for the raw milk sample from the storage tank, $15 \times 10^{6} \mathrm{UFC} / \mathrm{ml}$ were counted.

Determination of coliform bacteria. For the sample of raw milk in the storage tank, $150 \times 10^{3} \mathrm{MPN} / \mathrm{ml}$ were obtained (Table 3).

Microbioligical evaluations on the staff and implements. Of all the staff that works in the dairy workshop, Streptococcus spp. was isolated from the throat; on the nipple cups of the milking machine, the presence of E. coli was detected.

\section{Fast tests on the platforms and implications on the quality of the milk as raw material}

Sensory evaluation. The results from these tests are presented in Table 4.

Cuadro 3. Determinación de microorganismos mesofílicos y coliformes en leche de la Unidad de Lácteos Xochimancas.

Table 3. Determination of mesophile and coliform microorganisms in milk from the Xochimancas Dairy Unit.

\begin{tabular}{llcc}
\hline $\begin{array}{c}\text { Etapa del } \\
\text { proceso }\end{array}$ & $\begin{array}{c}\text { Unidad de } \\
\text { muestreo }\end{array}$ & $\begin{array}{c}\text { Número de } \\
\text { mesofílicos } \\
(\mathrm{UFC} / \mathrm{ml})\end{array}$ & $\begin{array}{c}\text { Número de } \\
\text { coliformes } \\
(\mathrm{NMP} / \mathrm{ml})\end{array}$ \\
\hline Ordeña & Vaca 1799 & $* 5 \times 104$ & $\leq 3$ \\
& Vaca 1503 & $115 \times 102$ & $\leq 3$ \\
Almacenamiento & $\begin{array}{l}\text { Tanque de } \\
\text { leche bronca }\end{array}$ & ${ }^{*} 15 \times 106$ & $* 150 \times 103$ \\
& & \\
\hline
\end{tabular}

*Por encima del límite máximo permitido por la NOM-243SSA-2010. Above the maximum limit allowed by the NOM243- SSA-2010. 


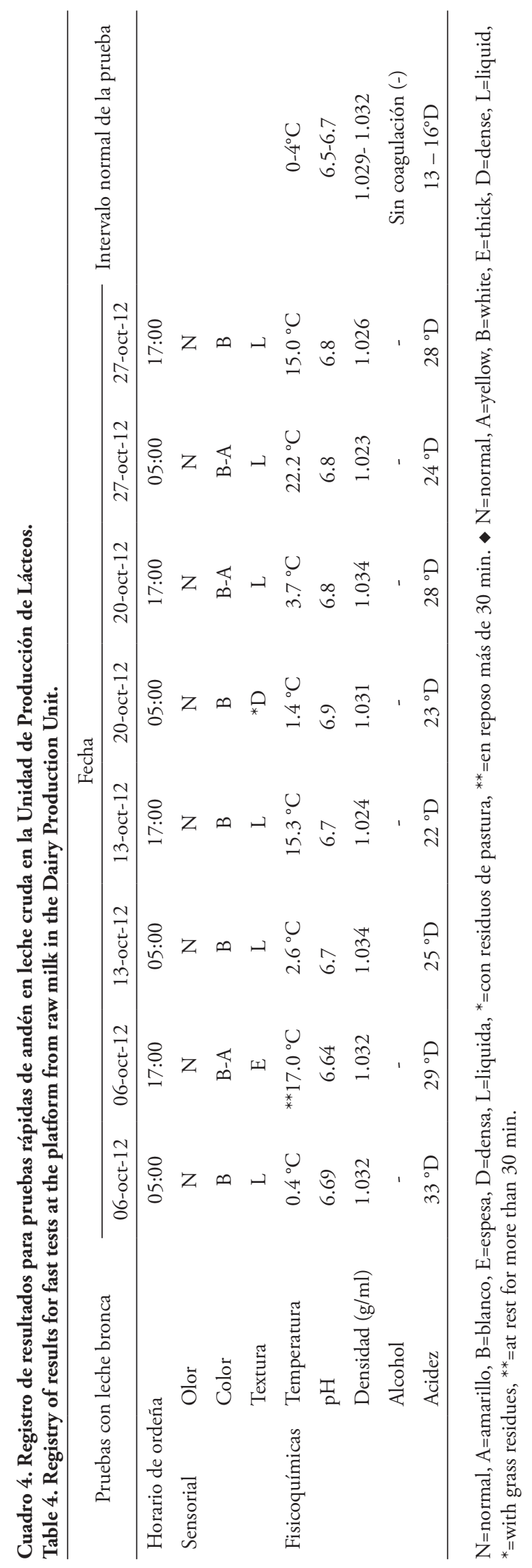


Los resultados obtenidos en el conteo de bacterias mesofílicas y coliformes, tanto en muestras de leche como en los productos lácteos, exceden los límites máximos permitidos por la NOM-243-SSA1-2010 "Productos y servicios. Leche, fórmula láctea, producto lácteo combinado y derivados lácteos", que indica que no deberán contener más de $100 \mathrm{UFC/g}$ de microorganismos no patógenos y $0 \mathrm{UFC/g}$ de organismos patógenos, como Salmonella spp, Staphylococcus aureus y Listeria monocytogenes y, además, contener menos de $3 \mathrm{NMP} / \mathrm{g}$ por $\mathrm{ml}$ de producto; esto es un indicador de que hay problemas de contaminación durante el proceso, pudiendo ser los utensilios para la elaboración de productos lácteos, agua, empaquetado, higiene de la mesa de trabajo, operador o refrigeración inadecuada. El conteo de mesofílicos aerobios para leche cruda directa de las vacas, con respecto al obtenido en el primer muestreo, reflejan un manejo inadecuado de la rutina del ordeño; por ello, se requiere la desinfección de los pezones antes y después del ordeño, lavado y secado. La mala higiene de las manos del operador, maquina ordeñadora y el entorno, son un medio de contaminación más factible para la leche cruda. El área de almacenamiento de la unidad de lácteos es una fuente de contaminación principal para la leche cruda, debido a que en el conteo bacteriológico para la determinación de bacterias mesofílicas realizado en las dos etapas de muestreo del presente trabajo, no hubo mejora alguna, debido a la falta de limpieza de los tanques de almacenamiento, malos hábitos de higiene de los operarios y una deficiente refrigeración de la leche. Al realizar un comparativo con los resultados obtenidos en la primera etapa de muestreo para la determinación de bacterias coliformes, se aprecia que la cuenta es significativamente menor, haciendo hincapié en la importancia de las prácticas de limpieza de los tanques de almacenamiento y desinfección de manos por parte del personal que labora en la unidad de lácteos. Los animales de esta unidad cuentan con certificado de hato libre de brucelosis y tuberculosis; ambas enfermedades se asocian a la introducción de animales nuevos al hato, por lo que la contaminación que se encuentra en los productos de esta empresa se debe al manejo inadecuado del producto. En un estudio similar realizado por Perdomo (2010) en cuatro abastecedores de productos lácteos, se obtuvieron datos donde la leche con mayor grado de contaminación se encontraba por encima de los $3000000 \mathrm{UFC} / \mathrm{mL}$.
The results obtained in the mesophile and coliform bacteria count, both in milk samples and in dairy products, exceed the maximum limits allowed by the NOM-243-SSA1-2010 "Products and services. Milk, dairy formula, combined dairy product and dairy products", which indicates that there shouldn't be more than $100 \mathrm{UFC/g}$ of nonpathogen microorganisms and $0 \mathrm{UFC/g}$ of pathogen organisms, such as Salmonella spp., Staphylococcus aureus and Listeria monocytogenes and, in addition, contain less than $3 \mathrm{MPN} / \mathrm{g}$ by $\mathrm{ml}$ of the product; this is an indicator that there are contamination problems during the process, which could be the utensils for dairy product elaboration, the water, the packaging, the hygiene of the work table, the operator or inadequate refrigeration. The aerobic mesophile count for raw milk direct from the cows, in comparison to that obtained from the first sample, reflects an inadequate management in the milking routine; therefore, the disinfection of nipples before and after milking, washing and drying, is required. Bad hygiene of the operator's hands, the milking machine and the environment represents a more feasible means of contamination for raw milk. The storage area of the dairy unit is a principal source of contamination for raw milk, because in the bacteriological count for the determination of mesophile bacteria during the two stages of the sampling in this study, there was no improvement, due to the lack of cleaning of the storage tanks, bad hygiene habits of the operators, and a deficient refrigeration of the milk. When performing a comparison with the results obtained during the first stage of the sampling for the determination of coliform bacteria, it can be seen that the count is significantly lower, emphasizing the importance of cleaning practices of the storage tanks and hand disinfection by the staff that works in the dairy unit. The animals in this unit have the certificate for herd free of brucellosis and tuberculosis; both diseases are associated with the introduction of new animals into the herd, which is why the contamination that is found in the products of this company is due to an inadequate management of the product. In a similar study carried out by Perdomo (2010) in four suppliers of dairy products, data were obtained where the milk with a higher degree of contamination was above the $3000000 \mathrm{UFC} / \mathrm{mL}$. This shows that with regards to the hygienic-sanitary quality in milk 
Esto nos muestra que en lo que respecta a la calidad higiénico-sanitaria en plantas procesadoras de leche de otras regiones del país, también existe el mismo problema, lo que se traduce en productos lácteos de mala calidad sanitaria que están a la venta en el mercado, y que ponen en riesgo la salud del consumidor.

En un estudio realizado por Félix y Meza (2004) en Ciudad Obregón, Sonora, se encontró que en productos alimenticios de consumo fresco, $32 \%$ de las muestras de lácteos rebasaron la especificación microbiológica para microorganismos mesofílicos aerobios, y más de $70 \%$ de las muestras analizadas superaron las especificaciones sanitarias para coliformes totales y fecales. En 2005, Vargas y Hernández (2005) realizaron un estudio en el estado de Tabasco sobre la calidad microbiológica de los quesos, en el que se encontró que $41.7 \%$ de las muestras se encuentran contaminadas por coliformes fecales, sin presencia de microorganismos patógenos. Esto nos indica que en los sistemas lecheros de producción de lácteos a nivel nacional existe un importante aumento en el cumplimiento de la normatividad, sobre todo en la aplicación de las prácticas de higiene y sanidad por parte del personal que manipula los lácteos, la adquisición de material y equipo inocuo para el proceso de los quesos, así como el mejoramiento de la infraestructura del taller de lácteos de esta empresa familiar.

A partir del desarrollo de esta investigación, la empresa incorporó la prueba de California para la detección de mastitis subclínica. Los resultados de la misma evidenciaron que la salud de la ubre de las vacas es buena, pues solamente uno de los animales presentó mastitis subclínica y, al mezclarse su leche con la de los otros, repercute en los análisis de procesos posteriores, debido a que la pezonera de la máquina de ordeño es utilizada en todo el hato y sólo se realiza una limpieza al final del mismo; se recomienda que el animal que presente inflamación en alguna glándula sea ordeñado manualmente. La vaca con mastitis subclínica fue tratada hasta recuperarse la salud de la ubre: sin embargo, antes de diagnosticar al animal con mastitis subclínica, la leche producida por éste no fue separada y se utilizó en el proceso de la elaboración de lácteos. El mezclar la leche pudo impactar la calidad de sus derivados, principalmente en la elaboración de queso, debido a que las leches que presentan un alto contenido de células somáticas tienen un porcentaje elevado de microorganismos, y las enzimas proteolíticas dañan la caseína y los glóbulos de grasa processing plants of other regions in the country, there is also the same problem, which translates into dairy products of bad sanitary quality that are on sale in the market, and which place the health of the consumer at risk.

In a study performed by Félix y Meza (2004) in Ciudad Obregón, Sonora, it was found that in dietary products of fresh consumption, $32 \%$ of the dairy samples exceeded the microbiological specification for aerobic mesophile microorganisms, and more than $70 \%$ of the samples analyzed exceeded the sanitary specifications for total and fecal coliforms. In 2005, Vargas and Hernández (2005) carried out a study in the state of Tabasco about the microbiological quality of cheeses, in which it was found that $41.7 \%$ of the samples are contaminated by fecal coliforms, without presence of pathogen microorganisms. This indicates that in the milk systems of dairy production at the national level, there is an important increase in the compliance to regulations, particularly in applying hygiene and sanitary practices by the staff that manipulates dairy products, as well as in acquiring material and innocuous equipment for cheese processing, and improving the infrastructure of the dairy workshop of this family enterprise.

From the development of this research, the company incorporated the California test for the detection of subclinical mastitis. Its results evidenced that the health of the cow's udder is good, since only one of the animals presented subclinical mastitis and, when mixing its milk with that of others, it affects the analysis of later processes, because the nipple cup of the milking machine is used with the whole herd and it is only cleaned at the end of that; it is recommended that the animal that presents inflammation on any gland be milked manually. The cow with subclinical mastitis was treated until the health of the udder was regained; however, before diagnosing the animal with subclinical mastitis, the milk produced by it was not separated, and it was used in the process of dairy elaboration. When mixing the milk, it could have an impact on the quality of the products, primarily in cheese elaboration, since milks that present a high content of somatic cells have a high percentage of microorganisms, and proteolytic enzimes damage the casein, and the fat globules become more susceptible to lipolysis, causing rancid flavors and a shorter shelf life. The greatest part of the enzymatic damage occurs within the udder, before milking; therefore, 
se vuelven más susceptibles a la lipolisis, provocando sabores rancios y una vida de anaquel menor. La mayor parte del daño enzimático ocurre dentro de la ubre, antes del ordeńo; por lo tanto, al aumentar la concentración de células somáticas, las pérdidas de proteínas y de materia grasa se elevan.

\section{Conclusiones}

El conteo microbiológico para mesofílicos y coliformes es bajo en la leche cruda, pero aun así está por encima de lo especificado en la NOM-243SSA1-2010. El conteo microbiológico para mesofílicos y coliformes, en las dos etapas de muestreo, se incrementa cuando la leche bronca es depositada en los tanques de almacenamiento. Es necesario que el personal que labora en la unidad de lácteos conozca las buenas prácticas de higiene y de manufactura para disminuir las cargas microbiológicas y cumplir con las normas establecidas, para asegurar así la salud del consumidor. La contaminación durante el manejo de la leche ejemplifica la situación de producción de lácteos artesanales. Consideramos que se requiere continuar con el apoyo técnico para la mejora de estos procesos, ya que la producción artesanal de leche es un volumen importante de la producción y el consumo del país. Los resultados obtenidos son sólo una muestra de lo que ocurre en varias unidades de producción de leche en el país, donde no se cumple con las especificaciones microbiológicas de las normas oficiales mexicanas, poniendo en riesgo la salud de la población al vender productos contaminados con bacterias causantes de enfermedades zoonóticas, como brucelosis o tuberculosis, entre otras.

\section{Literatura Citada}

Blowey R., y P. Edmondson. 1995. Control de la Mastitis en Granjas de Vacuno de Leche. Acribia. Zaragoza. 87 p.

Carter R. 1984. Diagnostic Procedures in Veterinary Bacteriology and Mycology. Charles C Thomas Publisher. 1984.

Castelán O., R. Matthewman., M. González E., y G. Burgos. 1997. Caracterización y Evaluación de los Sistemas Campesinos de Producción de Leche: El caso de Dos Comunidades del Valle de Toluca. Ciencia Ergo Sum. 3161997.

Castro L., G. Sánchez., E. Iruegas., y G. Saucedo. 2001. Tendencias y oportunidades de desarrollo de la red leche en México. In: FIRA Boletín Informativo. Volumen XXXIII, Año XXX. México.

Espinoza-Ortega, A. A., Álvarez-Macías, M., Del Valle C., y M., Chauvete. 2005. La Economía de los Sistemas Campesinos de Producción de Leche en el Estado de México. Tec Pecu Méx, 24: 320004. when increasing the concentration of somatic cells, the loss of proteins and fatty matter increases.

\section{Conclusions}

The microbiological count for mesophiles and coliforms is low in raw milk, but even so it is above that specified in the NOM-243-SSA1-2010. The microbiological count for mesophiles and coliforms in the two stages of sampling increases when the raw milk is placed in the storage tanks. It is necessary for the staff that works at the dairy unit to understand good practices for hygiene and manufacture, in order to decrease the microbiological loads and comply with the regulations established, to guarantee the health of the consumer. Contamination during milk management exemplifies the situation of artisanal dairy production. We consider that it is necessary to continue with technical support to improve these processes, since the artisanal production of milk represents an important volume of the production and consumption in the country. The results obtained are just a sample of what happens in several milk production units in the country, where there is no compliance with the microbiological specifications of the Mexican official norms, putting at risk the health of the population by selling products contaminated with bacteria that cause zoonotic diseases such as brucellosis and tuberculosis, among others.

- End of the English version -

Félix F., y M. Meza. 2004. Calidad Sanitaria de Alimentos Disponibles al Público de Ciudad Obregón, Sonora, México.

Fideiscomisos Instituidos en Relación con la Agricultura (FIRA). Disponible en: http://www.fira.gob.mx/Nd/index.jsp

Lampkin, N. 1990. Organic Farming. Farming Press Books, Ipswich, UK. EUA.

Muchnik, J. 2006. Identidad Territorial y Calidad de los Alimentos, Procesos De Calificación y Competencias de los Consumidores. Agroalimentaria 2: 200.

Norma Oficial Mexicana NOM-243-SSA1. 2010. Productos y Servicios. Leche, Fórmula Láctea, Producto Lácteo Combinado y Derivados Lácteos. Disposiciones y Especificaciones Sanitarias. Métodos de Pruba.

FAO (Organización de las Naciones Unidas para la Alimentación y la Agricultura). Disponible en: http://www.fao.org/home/ es/

UNESCO (Organización de las Naciones Unidas para la Educación, la Ciencia y la Cultura). Disponible en: http://www. unesco.org/new/es/

Perdomo, N., 2010. Evaluación de la Calidad Microbiológica de Leche y Queso Fresco “de prensa” Artesanal Elaborado en el 
Municipio de Jesús Carranza, Veracruz, México. Tesis de Licenciatura de la Universidad Veracruzana. Veracruz, México. PROY-NMX-F-700-COFOCALEC-2012. Sistema Producto Leche - Alimento - Lácteo - Leche Cruda De Vaca - Especificaciones Fisicoquímicas, Sanitarias y Métodos de Prueba.
Slack Mary, and D. B. Wheldon B. 1978. A Simple and Safe Volumetric Alternative to the Method of Miles, Misra and Irwin for Counting Viable Bacteria. J. Med. Microbiol. 11: 5411978.

Vargas G., y V. Hernández. 2005. Calidad Microbiológica de los Quesos Frescos en Tabasco. Salud en Tabasco. 13:56005. 